\title{
GENETIC CHARACTERISTICS OF EGYPTIAN BUFFALO USING DNA MICROSATELLITE MARKERS
}

\author{
S. Abou-Bakr ${ }^{1}$, M.A.M. Ibrahim ${ }^{1}$, Y.M. Hafez ${ }^{1}$, M. Attia ${ }^{1}$, S.M. Abdel-Salam ${ }^{1}$,W. \\ Mekkawy $^{2}$
}

1- Animal Production Department, Faculty of Agriculture, Cairo University, Giza, Egypt, 2- Animal

Production Department, Faculty of Agriculture, Ain Shams University, Cairo, Egypt

\section{SUMMARY}

To evaluate the genetic polymorphism for DNA microsatellite markers of Egyptian buffalo, 471 unrelated Egyptian buffalo were genotyped with 11 microsatellite markers. The data were analyzed with GenALEx6 software. Nine (82\%) of the microsatellite markers were polymorphic and two (18\%) were monomorphic. A total 198 alleles were detected, with the number of alleles per marker ranging from 17 (RM28 and BM415) to 29 (BMC4203), giving a mean number of 22 \pm 1.302 alleles per marker. The effective number of alleles was lower than the observed values with a mean value of $16.502 \pm 1.137$ per marker. The most frequent alleles were ranged from 0.086(BMC4203) to 0.127 (BM415). The mean observed and expected homozygosity was 0.113 and 0.063 , respectively, while the observed and the expected heterozygosity was 0.887 and 0.937, respectively, over all loci. Polymorphism information content values were ranged from 0.909 (BM415) to 0.949 (ILSTS093 andILSTS097). At the nine microsatellite loci, the mean of fixation index was 0.052. Successful genotyping of Egyptian buffalo using these DNA microsatellite markers suggests that the latter can be a valuable resource for genome analysis in Egyptian buffalo.

\section{Keywords: Egyptian buffalo, microsatellite DNA, polymorphism}

\section{INTRODUCTION}

The Egyptian buffalo (Bubalus bubalis) contributes significantly to the agricultural economy and food security in Egypt. Also, buffalo is the main dairy animal in Egypt, in addition to being an important source of red meat. Annual milk and meat production from buffaloes are 2,640,638 and 169,013.57 tons, respectively, contributing to 49 and $40 \%$ from the total national milk and meat production in Egypt, respectively (MALR,2008). Genetic maps provide new insights into genome structure and chromosomal architecture of the genome, and also serve as framework for identification and location of genes linked with economically important traits. Except for water buffalo, the genetic maps have been reported for most of the important livestock species. To develop genetic maps of water buffalo, identification and characterization of polymorphic microsatellite markers is a prerequisite (Nagarajan et al., 2009).

DNA markers-based technologies enable the detection of different polymorphic types. Among those, microsatellites or short tandem repeats (STR) or simple sequences repeats (SSR) have been identified in all the eukaryotic species that have been investigated thus far (Ron et al., 1996). The use of microsatellites in population genetics has so far been mainly reported in buffalo population
(Zhang et al., 2007; Kumar et al., 2006 and Van Hooft et al., 2002).

Several studies had shown that repeated flanking sequences of microsatellite markers are often conserved between related species, allowing cross-species amplification (Schlotterer et al., 1991; Moore et al., 1994; Kemp et al., 1995; Levin et al., 1995; Moore et al., 1995; Liu et al., 1996 and Primmer et al., 1996). These markers can be used in the characterization of species populations, genetic diversity (Esmaeilkhanian and Banabazi, 2006) and population studies (Arora et al., 2004 and Amirinia et al., 2007), as they are hyper variable and widely dispersed through genome. Moreover, they have application in the identification of individuals and parentage testing (Marklund et al., 1994; Luikart et al., 1999, Seyedabadi et al., 2006 and Bhuyan et al., 2010).

Researchers applied cattle microsatellite markers for defining the genome make up in buffalo because no systematic studies have been undertaken to develop polymorphic DNA markers specific to these species (Shokrollahi et al., 2009). Hassanane et al. (2007) indicated the successful genotyping of bovine microsatellites in the Egyptian buffalo genome.

Genetic characterization of each breed is necessary for its effective and meaningful improvement and conservation (Sajid et al., 2007). So, it is essential to characterize 
buffalo at the molecular level for their effective use in the genetic improvement programs (Saifi et al., 2004).

The purpose of the present study was to genetically characterize Egyptian buffalo using 11 DNA microsatellite markers.

\section{MATERIALS AND METHODS}

\section{Selection of Buffaloes and Blood Sample Collection:}

A total of 471 unrelated multiparous lactating buffaloes (Different families having no blood relation) represented seven different farms in six different governorates were utilized in this experiment. Also, there was no pedigree information available on these animals. A volume of $10 \mathrm{ml}$ peripheral blood was collected from the jugular vein in Falcon tubes supplied with proper amount of EDTA. Field blood samples (471) were placed on a cooling gel in an ice box immediately after their collection and brought to the Animal Biotechnology Lab., established by a grant no.218, financed by Science and Technology Development Fund (STDF) and located in Faculty of Agriculture, Cairo University, Giza, Egypt and stored temporarily at $-20^{\circ} \mathrm{C}$ before DNA extraction.

\section{DNA Extraction:}

DNA was isolated from the peripheral leukocytes using Fermentas ${ }^{\circledR}$ kits, Cat. No. k0512, Fermentas Life Science, EU, according to Sambrook and Russel, 2000.

The Yield, concentration and purity of DNA of the samples were quantified using ScanDrop ${ }^{\circledR} 200$, Anyltikajena, UK. The whole genome of each sample was run in $0.8 \%$ agarose gel through a horizontal gel electrophoresis system (mini gel, Biometra ${ }^{\circledR}$ EU). Standard DNA/DNA ladder was used and all samples were brought at the same concentration level $(50 \mathrm{ng} / \mu \mathrm{l})$.

\section{Microsatellite DNA Markers Selection:}

Microsatellite DNA markers are highly polymorphic and abundant often found in noncoding region of genes (Rohrer et al., 1998). A total of 11 Microsatellite DNA markers located in chromosome 7 in buffalo were utilized. The information about these DNA markers is given in Table 1.

\section{Amplification of the microsatellite Markers and Genotyping:}

The PCR was carried out on $50 \mathrm{ng}$ of the genomic DNA in a $20 \mu \mathrm{l}$ reaction volume of $50 \mathrm{mM}$ KCL, $10 \mathrm{mM}$ Tris-Hcl (pH 8.8), 200 $\mu \mathrm{M}$ dNTP, $1.5 \mathrm{mM} \mathrm{MgCl2,} 5$ Pmol of each primer and $1.0 \mathrm{U}$ Taq DNA polymerase. The amplification was realized using thermal cycler (G-Storm ${ }^{\circledR}$, Gene Technologies, UK) machine.
The primary denaturation was done at $95{ }^{\circ} \mathrm{C}$ for 3 minutes followed by 10 cycles of denaturation at $94^{\circ} \mathrm{C}$ for $30 \mathrm{sec}$., the annealing temperature at $58.5-59.5^{\circ} \mathrm{C}$ (decrease in temperature set $1^{\circ} \mathrm{C}$ after each cycle) for 30 sec. and the extension at $72^{\circ} \mathrm{C}$ for $45 \mathrm{sec}$. Following these cycles with variant annealing temperatures (Table 1), 30 cycles with constant annealing temperature at $54^{\circ} \mathrm{C}$ were performed and the reaction ended with final extension at $72^{\circ} \mathrm{C}$ for 5 minutes and final storage temperature of $4^{\circ} \mathrm{C}$.

\section{Data Analysis:}

The GenALEX version 6 package software (Peakall and Smouse, 2006) was employed to calculate allele frequencies and sizes, effective number, observed and expected heterozygosity, and fixation index. Polymorphic information content was estimated using $\mathrm{R}$ program (Gregory et al., 2011).

\section{RESULTS AND DISCUSSION}

Nine $(82 \%)$ of the studied markers were polymorphic and two (18\%) were monomorphic of 471 unrelated Egyptian buffaloes. Nagarajan et al. (2009), stated that a total of 571 microsatellite markers had been characterized for water buffalo. They found that among the amplified cattle markers, $85 \%$ of the markers were polymorphic, this percentage was in agreement with our study, and slightly high when compared with the other studies on water buffalo (Moore et al., 1995 and Navani et al., 2002). Navani et al. (2002) reported that $56 \%$ of cattle microsatellite markers provided polymorphic band patterns when tested in 25 buffaloes. Results of the amplification of the bovine microsatellite in buffalo and sheep genomes may be referring to the sharing of a common ancestry for cattle, buffalo and sheep after the divergence of subfamily bovine (Bos Taurus) from the family bovidae (Mattapallil and Ali, 1999).

The number of alleles per locus $(\mathrm{Na})$, effective number ( $\mathrm{Ne}$ ) of alleles, observed (Ho), expected (He) heterozygosity, and allele size are shown in Table 2. A total of 198 alleles were detected with an average number of alleles per polymorphic locus was $22 \pm 1.302$, ranging from 17 (RM28 and BM415) to 29 (BMC4203). Vijh et al. (2008) found that the number of alleles per locus ranged from 11 to 26 allele on Indian water buffalo. Also, Weibin et al. (2007) reported that a total of 247 alleles were detected with the number of alleles ranging from 13 to 33 , giving a mean number of 21 alleles per locus in Qinchuan cows. These differences in the number of alleles are 
due to the type of breed studied and the genetic polymorphism within the breed itself (Vallejo et al., 2003).

The average number of effective $(\mathrm{Ne})$ alleles per locus was $16.502 \pm 1.137$. Observed heterozygosity (Ho) varied from 0.517 (ILSTS097) to 0.995 (BM143), while expected heterozygosity $(\mathrm{He})$ varied from 0.916 (BM415) to 0.952 (ILSTS093). The overall mean of Ho and He values were $0.887 \pm 0.048$ and $0.937 \pm 0.004$, respectively. These results are in agreement with the study of Aminafshar (2008), who concluded that there were high mean percentages observed heterozygosity in three populations of Iranian buffalo using 15 cattle microsatellite.

Takezaki and Nei (1996) reported that the average heterozygosity must be between 0.3 and 0.8 in a population, in order to be a useful marker tool for measuring the genetic variation. Our results for mean heterozygosity were higher than that range. Therefore, the identified markers in this study are a suitable tool for measuring the genetic variation.

Mirhoseinie et al. (2005) concluded that the obtained results from heterozygosity indicated that the loci with more alleles contain higher rate of heterozygosity in both cattle and buffalo species.

At every microsatellite locus, allele size range was distinctive (Table 2). And at every locus, there was a most frequent allele (Table 3). At BM415 and RM28, the most frequent allele was 139 and $102 \mathrm{bp}$, respectively, which had an allele frequency of 0.127 and 0.122 , respectively.

Polymorphism information content (PIC), fixation index (F) and Shannon's information index (I) in Egyptian buffalo genome are shown in Table 3. Polymorphism information content (PIC) was estimated using allele frequencies in each polymorphic microsatellite locus, ranged from 0.909 (BM415) to 0.949 (ILSTSO93 and ILSTSO97), and mean PIC was 0.933 . The PIC is a parameter indicative of the degree of informative of a marker and another important measure of DNA polymorphism. The PIC reflects the probability that a given offspring of a parent carrying a rare allele at a locus will allow deduction of parental genotype at a locus (Babar et al., 2009). Genetic markers with PIC values of less than 0.25 are considered to be less informative and those with values more than 0.5 are reckoned as distinctly informative in population genetic studies (Botstein et al., 1980). Loci with many alleles and a PIC near one are most desirable (Botstein et al., 1980). Following the criteria of Botstein et al., (1980), in this study, all the nine microsatellite loci appeared to be highly informative (PIC $>0.5$ ) and thus will be useful to evaluate the genetic diversity in Egyptian buffalo.

Fiona and Tracey (1998), reported that the PIC values are generally slightly smaller than heterozygous values, if large numbers of unrelated animals are genotyped. The number of unrelated animals used to calculate these values does vary and thus reverse the trend that PICs are slightly lower than heterozygous values. This is in agreement with our study.

The fixation indices of BM415, BM1329, BMC4203 and BMS483 microsatellite loci were negative and the others were positive (Table 3). The mean of fixation indices was 0.052, reflecting that the degree of heterozygote defect at these loci was high.

In conclusion, this study declared that a large fraction of bovine DNA microsatellite markers can be amplified and is polymorphic in the Egyptian buffalo. Also, these DNA markers are applicable for population genetic studies on the Egyptian buffalo.

\section{ACKNOWLEDGEMENT}

The authors would like to acknowledge Science and Technology Development Fund (STDF), Egypt for the financial support of this work throughout the project grant no.218 titled "Microsatellite markers: as a tool for genetic improvement of milk yield and its contents in Egyptian buffaloes".

\section{REFERENCES}

Aminafshar, M., 2008. Phylogenetic study of the Iranian buffalo by microsatellite markers. In: Development of animal science, $\mathrm{PhD}$ Thesis, P.200. Tehran: Islamic Azad university-Science and Research branch.

Aminafshar, M.,C. and Amirinia, R. Vaez Torshizi, 2008. Genetic diversity in buffalo population of Guilan using microsatellite markers. J. Anim. and Vet. Advances, 7(11): 1499-1502.

Amirinia,C., H. Seyedabadi, M.H. Banabazi and M. Kamali, 2007. Bottleneck study and genetic structure of Iranian Caspian horse population using microsatellites. Pak. J. Biol. Sci., 9:1540-1543.

Arora, R., B.D. Lakhchaura, R.B. Prasad, M.S. Tantia and R.K. Vijh, 2004. Genetic diversity analysis of two buffalo populations of northern India using microsatellite markers. J. Anim. Breed. Genet., 121(2): 111-118.

Babar, M. E., T. Hussain, A. Nadeem, R.Jabeen and M. Javed, 2009. Genetic characterization of Azakheli Buffalo breed of Pakistan using microsatellite DNA 
markers. Pakistan, J. Zool. Suppl. Ser., 9:361-366

Bhuyan, D.K., M. L. Sangwan, V.C. Gole and R.K. Sethi, 2010. Studies on DNA fingerprinting in Murrah buffaloes using microsatellite markers. Ind. J. Biotechnol., 9: 367-370.

Botstein, R., L. White, M. Skolnick and R.W. Davis, 1980. Construction of a genetic linkage map in man using restriction fragment length polymorphisms, Am. J. Hum. Genet. 32: 314-331.

Esmaeilkhanian, S. and M. Banabazi, 2006. Genetic variation within and between five Iranian sheep populations using microsatellite markers. Pak. J. Biol. Sci., 13:2488-2492.

Fiona, C.B. and T. D. Tracey, 1998. Intrabreed polymorphic information content of microsatellite in cattle and sheep. Canad. J. Anim. Sci., 78:425-428.

Gregory Warnes, Gregor Gorjanc, Friedrich Leisch and Michael Man., 2011. Genetics: Population Genetics. R package version 1.3.6. http://CRAN.R-project.org/ package $=$ genetics

Hassanane, M.S., A.A. Zaki, S.Aabou-Bakr, R.R. Sadek, and A.A. Nigm, 2007.Genetic polymorphism of some microsatellites on chromosome seven in the Egyptian buffalo. Egypt. J. Anim. Prod., 44(2):97-110.

Kemp, S.J., O. Hishida, J. Wambugu, 1995. A panel of polymorphic bovine, ovine and caprine microsatellite markers. Anim. Genet., 26:299-306.

Kumar, S., J. Gupta, N. Kumar, K. Dikshit, N. Navani, P. Jain and M. Nagarajan, 2006. Genetic variation and relationships among eight Indian riverine buffalo breeds. Mol. Ecol., 15:593-600.

Levin, I., H.H. Cheng, C. Baxter-Jones and J. Hillel, 1995. Turkey microsatellite DNA loci amplified by chicken specific primers. Anim. Genet., 26:107-110.

Liu, Z., R. P. M.A. Crooijmans, J.J. Van Der Poel and M.A.M. Groenen, 1996. Use of chicken microsatellite markers in Turkey: a pessimistic view. Anim. Genet., 27:191193.

Luikart, G., M.P. Biju-Duval, O. Ertugrul, Y. Zagdsuren, C. Maudet and P. Taberlet, 1999. Power of 22 microsatellite markers in fluorescent multiplexes for parentage testing in goats (Capra hircus). Anim. Genet., 30: 431-438.

MALR, 2008. Ministry of Agriculture and Land Reclamation, Economic affairs sector, study of statistics for animal, poultry and fish wealth.

Marklund, S., H. Ellegren, S. Eriksson, K. Sandberg and L. Andersson, 1994. Parentage testing and linkage analysis in the horse using a set of highly polymorphic microsatellites. Anim. Genet., 25:19-23.

Mattapallil, M.J. and S. Ali, 1999. Analysis of conserved microsatellite sequences suggests closer relationship between water buffalo, Bubalus bubalis and sheep, Ovis aries. DNA Cell Biology, 18:513-519.

Mirhoseinie,S.Z, S.Z. F. Vahidie and B. Gharehyazie, 2005. Survey of efficiency of six microsatellite loci in Iranian indigenous cattle and buffalo populations. Iranian J. Biotech., 3(1):41-47.

Moore, S. S., K. Byrne, K.T. Berger, 1994. Characterization of 65 bovine microsatellites. Mammalian Genome,5:8490.

Moore, S.S., D. Evans, K. Byrne, 1995. A set of polymorphic DNA microsatellites useful in swamp and river buffalo (Bubalus bubalis). Anim. Genet., 26:355-359.

Nagarajan, M., N. Kumar, G. Nishanth, R. Haribaskar, K. Paranthaman, J. Gupta, M. Mishra, R. Vaidhegi, S. Kumar, A.K. Ranjan and S. Kumar, 2009. Microsatellite markers of water buffalo, Bubalus bubalisdevelopment, characterization and linkage disequilibrium studies. BMC Genet., 10:6875.

Navani ,N., PK. Jain, S. Gupta, BS. Sisodia and S. Kumar, 2002. A set of cattle microsatellite DNA markers for genome analysis of riverine buffalo (Bubalus bubalis). Anim. Genet., 33:149-154.

Peakall, R. and P.E. Smouse, 2006 GENALEX 6: Genetic analysis in Excel. Population genetic software for teaching and research. Mol. Ecol. Notes, 6:288-295.

Primmer, C.R., A.P. Moller and H. Ellegren, 1996. A wide-range survey of cross-species microsatellite amplification in brids. Molecular Ecology, 5: 365-378.

Rohrer, G.A.,R.T. Stone, Z. Wang and D. Troyer, 1998. Rapid communication: identification of two microsatellite loci that map to porcine chromosome 3. J. Anim. Sci., 76:1503-1504.

Ron, M., Y. Blanc, M. Band, E. Ezra, JI Weller, 1996. Misidentification rate in Israeli dairy cattle population and its implications for genetic improvement. J. Dairy Sci., 79:676-681.

Saifi, H.W., B. Bhushan, S. Kumar, P. Kumar, B.N. Patra and A. Sharma, 2004. Genetic identity between Bhadawari and Murrah breeds of Indian Buffaloes (Bubalus bubalis) using RAPD-PCR. Asian-Aust. J. Anim. Sci., 17:603-607.

Sajid, I.A., M.E. Babar and K. Javed, 2007. Genetic diversity of Nili-Ravi from Nili and Ravi buffalo breeds of Pakistan. Italian J. Anim. Sci., 6:314-317. 
Sambrook J. and Russell, D. W., 2000. Molecular cloning: A Laboratory Manual. 3rd revised edition, vol 1, Cold Spring Harbor Laboratory press, USA.

Schlotterer, C., B. Amos and D. Tautz, 1991. Conservation of polymorphic simple sequence loci in cetacean species. Nature, 354:63-65.

Seyedabadi, H., C. Amirinia, MH. Banabazi and H. Emrani,2006. Parentage verification of Iranian Caspian horse using microsatellite markers. Iran. J. Biotechnol. 4: 260-264.

Shokrollahi, B., C. Amirinia, N. D. Djadid, N. Amirmozaffari and M.A. Kamali, 2009. Development of polymorphic microsatellite loci for Iranian river buffalo (Bubalus bubalis). African J. Biotechnol. 8(24): 6750-6755.

Takezaki, N. and M. Nei, 1996. Genetic distances and reconstruction of phylogenetic trees from microsatellite DNA. Genetic, 144: 389-399.
Vallejo,R.L., Y.L. Li, G.W. Rogers and M.S Ashwell, 2003. Genetic diversity and background linkage disequilibrium in the North American Holstein cattle population. J. Dairy Sci., 86:4137-4147.

Van Hooft, W.F., A, F. Groen and H.H.T. Prins, 2002. Microsatellite analysis of genetic diversity in African buffalo population throughout Africa. Mol. Ecol., 9:2017-2025.

Vijh, R.K., M.S. Tantia, B.Mishra and S.T. Bharani Kumar, 2008. Genetic relationship and diversity analysis of Indian water buffalo (Bubalus bubalis). J. Anim. Sci., 86:1495-1502.

Weibin, S., H. Chen, C. Lei, X. Lei and Y. Zhang, 2007. Study on population genetic characteristics of Qinchuan cows using microsatellite markers. J. Genet. and Genomics, 34(1):17-25.

Zhang, Y., D. Sun, and Y.Yu, 2007, Genetic diversity and differentiation of Chinese domestic buffalo based on 30 microsatellite markers. Nnim. Genet., 38(6): 569-575.

Table 1. Characterization of the relevant DNA microsatellite markers in chromosome six in cattle

\begin{tabular}{|c|c|c|c|c|c|c|}
\hline $\begin{array}{l}\text { Marker } \\
\text { Name }\end{array}$ & $\begin{array}{l}\text { Physical } \\
\text { map } \\
\text { name }\end{array}$ & Primer sequence & $\begin{array}{l}\text { Annealing } \\
\text { Temperature } \\
{ }^{\circ} \mathrm{C}\end{array}$ & $\begin{array}{l}\text { Minimum } \\
\text { Allele } \\
\text { size (bp) }\end{array}$ & $\begin{array}{l}\text { Maximum } \\
\text { Allele } \\
\text { size (bp) }\end{array}$ & $\begin{array}{l}\text { No. of } \\
\text { alleles } \\
\text { in } \\
\text { cattle }\end{array}$ \\
\hline ILSTS93 & D6S22 & $\begin{array}{l}\text { TGAAATATACCTGAGTAGCAGC } \\
\text { TTGTTTTAACTCCCCACCCC }\end{array}$ & 58.7 & 179 & 202 & 19 \\
\hline BM1329 & D6S14 & $\begin{array}{l}\text { TTGTTTAGGCAAGTCCAAAGTC } \\
\text { AACACCGCAGCTTCATCC }\end{array}$ & 58.7 & 137 & 161 & 9 \\
\hline BM143 & D6S13 & $\begin{array}{l}\text { ACCTGGGAAGCCTCCATATC } \\
\text { CTGCAGGCAGATTCTTTATCG }\end{array}$ & 58 & 90 & 122 & 13 \\
\hline BM415 & D6S10 & $\begin{array}{l}\text { GCTACAGCCCTTCTGGTTTG } \\
\text { GAGCTAATCACCAACAGCAAG }\end{array}$ & 54 & 141 & 173 & 15 \\
\hline RM28 & D6S4 & $\begin{array}{l}\text { CTACAGTCATGGGTCTGAAAGAG } \\
\text { ATCTTCAGCCTGGCCTGAGAG }\end{array}$ & 62 & 94 & 110 & 5 \\
\hline BMC4203 & D6S20 & $\begin{array}{l}\text { GCAAATGTAAGCTGAAGGCC } \\
\text { CCTGGGAAATCCCATGGAC }\end{array}$ & 60 & 144 & 170 & 10 \\
\hline ILSTS97 & D6S23 & $\begin{array}{l}\text { AAGAATTCCCGCTCAAGAGC } \\
\text { GTCATTTCACCTCTACCTGG }\end{array}$ & 58 & 234 & 244 & 3 \\
\hline AFR227 & D6S18 & $\begin{array}{l}\text { GACCAACTGAGTGCATGCACG } \\
\text { TCATTGAGCAGGAGTAGGATTGAGA }\end{array}$ & 58 & 96 & 120 & 11 \\
\hline BMS483 & D6S51 & $\begin{array}{l}\text { GGTATGAGACCAGGTGTGGG } \\
\text { CAGGGCCACATTTCCAAG }\end{array}$ & 56 & 109 & 117 & 5 \\
\hline ILSTS90 & D6S21 & $\begin{array}{l}\text { TAGTACCATACCCAGGTAGG } \\
\text { GCCAAAACACACAAGTGTGC }\end{array}$ & 58 & 143 & 147 & 3 \\
\hline BM4528 & D6S12 & $\begin{array}{l}\text { CAGAATCCATACACATGTCAACA } \\
\text { AGGAACAGGTATAGGAATATTGGA }\end{array}$ & 58 & 238 & 276 & 7 \\
\hline
\end{tabular}


Table 2. Genetic estimates for the Egyptian buffalo

\begin{tabular}{lllllll}
\hline $\begin{array}{l}\text { Microsatellite } \\
\text { markers }\end{array}$ & N & Na & Ne & Ho & He & $\begin{array}{l}\text { Allele size } \\
\text { (bp) }\end{array}$ \\
\hline RM28 & 471 & 17 & 12.671 & 0.870 & 0.921 & $94-126$ \\
BM415 & 436 & 17 & 11.841 & 0.975 & 0.916 & $129-161$ \\
BM143 & 373 & 19 & 14.059 & 0.895 & 0.929 & $100-136$ \\
BM1329 & 323 & 24 & 17.943 & 0.994 & 0.944 & $123-169$ \\
AFR227 & 449 & 21 & 15.809 & 0.911 & 0.937 & $90-130$ \\
BMC4203 & 446 & 29 & 20.141 & 0.951 & 0.950 & $136-192$ \\
ILSTS093 & 179 & 24 & 20.698 & 0.899 & 0.952 & $183-229$ \\
ILSTS097 & 203 & 24 & 20.375 & 0.517 & 0.951 & $220-266$ \\
BMS483 & 393 & 23 & 14.976 & 0.972 & 0.933 & $100-144$ \\
Mean & 364 & 22 & 16.502 & 0.887 & 0.937 & -- \\
SE & & 1.302 & 1.137 & 0.048 & 0.004 & -- \\
\hline N & & & & &
\end{tabular}

$\mathrm{N}=$ number of samples per marker; $\mathrm{Na}=$ Number of different alleles; $\mathrm{Ne}=$ number of effective alleles; $\mathrm{Ho}_{0}$ Observed heterozygosity; $\mathrm{He}=$ Expected heterozygosity.

Table 3. Most frequent alleles and their frequencies, Polymorphism Information Content (PIC) and Fixation Index (F) of Egyptian buffalo

\begin{tabular}{lcccc} 
and Fixation Index (F) of Egyptian buffalo & & & \\
\hline $\begin{array}{l}\text { Microsatellite } \\
\text { markers }\end{array}$ & Allele & Frequencies & PIC & F \\
\hline RM28 & 102 & 0.122 & 0.916 & 0.055 \\
BM415 & 139 & 0.127 & 0.909 & -0.065 \\
BM143 & 110 & 0.113 & 0.924 & 0.036 \\
BM1329 & 135 & 0.088 & 0.941 & -0.052 \\
AFR227 & 112 & 0.104 & 0.933 & 0.028 \\
BMC4203 & 156 & 0.086 & 0.948 & -0.0003 \\
ILSTS093 & 195 & 0.064 & 0.949 & 0.055 \\
ILSTS097 & 236 & 0.076 & 0.949 & 0.056 \\
BMS483 & 116 & 0.111 & 0.929 & -0.042 \\
\hline
\end{tabular}

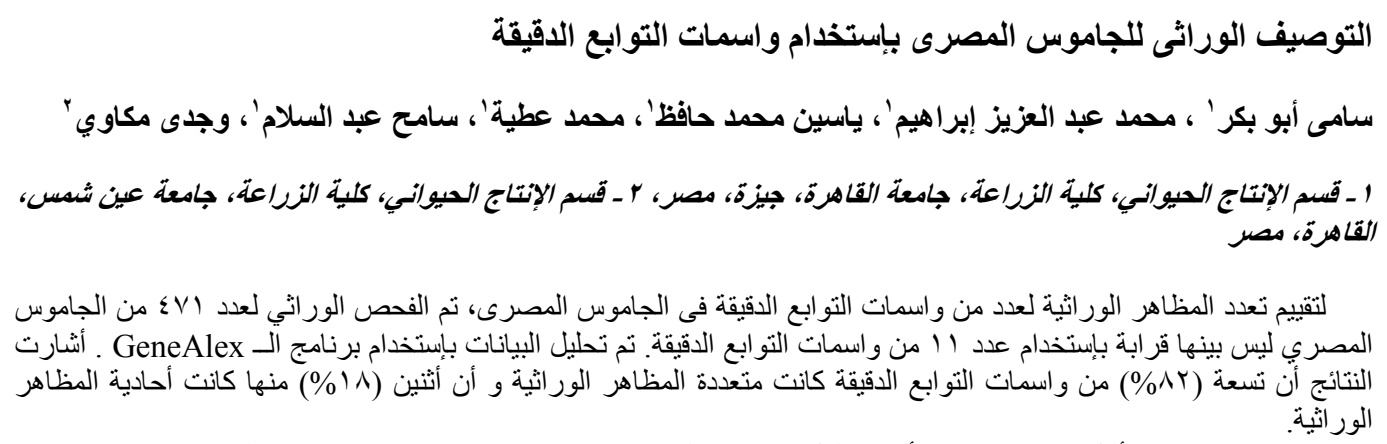

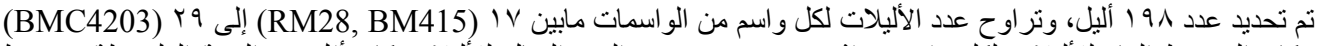

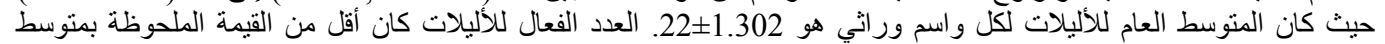

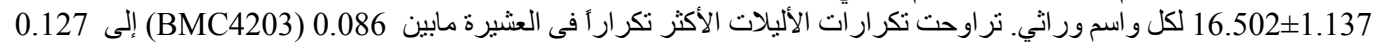

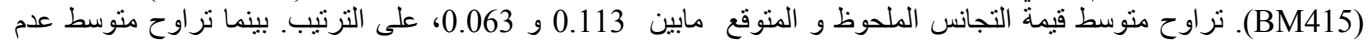

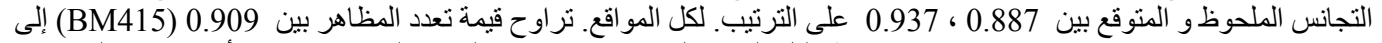

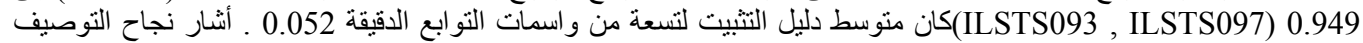

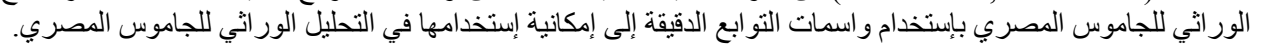

